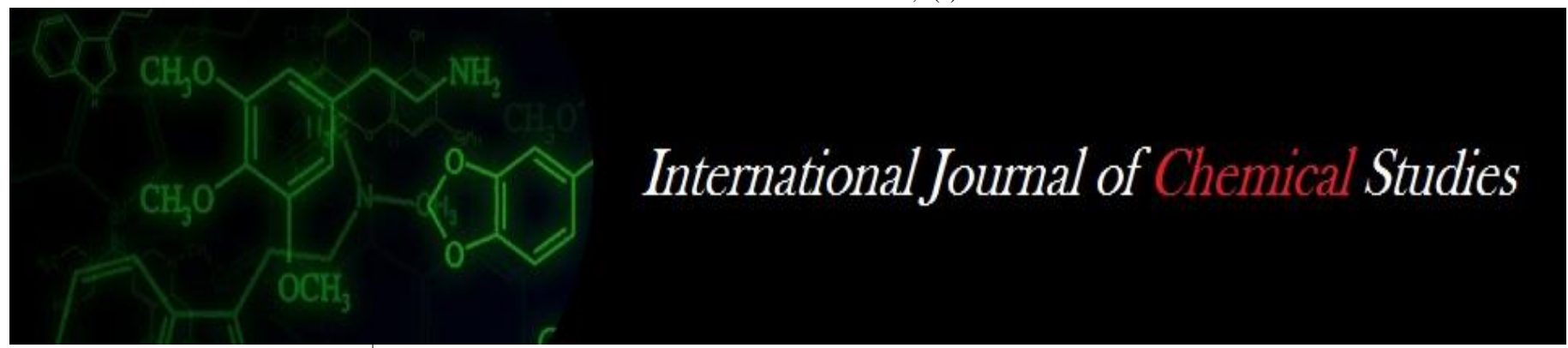

P-ISSN: 2349-8528

E-ISSN: 2321-4902

IJCS 2020; 8(1): 1785-1787

(C) 2020 IJCS

Received: 19-11-2019

Accepted: 21-12-2019

\section{GN Yadav}

Research Scholar,

Dr. Panjabrao Deshmukh Krshi

Vidyapeeth, Akola,

Maharashtra, India

\section{SL Yadav}

Assistant Professor,

Dr. Panjabrao Deshmukh Krshi

Vidyapeeth, Akola,

Maharashtra, India

\section{AB Chorey}

Associate Professor,

Dr. Panjabrao Deshmukh Krshi

Vidyapeeth, Akola,

Maharashtra, India

\section{Response of different phenophase under summer guar gum conditions (Cyamopsis tetragonoloba (L.) Taub.)}

\section{GN Yadav, SL Yadav and AB Chorey}

DOI: https://doi.org/10.22271/chemi.2020.v8.i1z.8524

\begin{abstract}
An experiment was conducted on clay loam soil, at Agronomy farm, Dr. Panjabrao Deshmukh Krishi Vidyapeeth, Akola during the summer season of 2015. To investigate the effect of irrigation levels and spacings on growing degree days and correlation coefficient of summer guar gum. The study revealed that, among the irrigation levels yield and yield attributing traits differ significantly correlated. Number of pods plant ${ }^{-1}(0.747)$ and number of seeds $\operatorname{pod}^{-1}(0.719)$ with seed yield plant ${ }^{-1}$ showed highly significant correlations. Days required for completion of different phenophases were significantly influenced by irrigation level at 0.6 IW/CPE recorded significantly less days required for completion of different phenophases at growth stages i.e. 50\% flowering, pod initiation, pod filling stage and harvesting as compared to other irrigation levels. Irrigation level at 1.2 IW/CPE recorded significantly higher growing degree days (day ${ }^{0} \mathrm{C}$ ) at different phenophases i.e. $50 \%$ flowering, pod initiation, pod filling and harvesting than other irrigation levels.
\end{abstract}

Keywords: Guar, phenophases, growing degree days, correlation coefficient, irrigation levels, spacings

\section{Introduction}

Water stress affects different growth and development stages of guar. Water need of gum guar may vary with the climatic conditions, stages of crop and type of soil. Hence, scheduling of irrigation at an appropriate time and in right amount is one of the most important factors for realizing high yield of summer gum guar, especially under scarce and costly irrigation water. Scheduling of irrigation based on climatological approach may provide information not only about water use of the crop, but also about the proper time of irrigation as suggested by Parihar et al. (1974) ${ }^{[3]}$. In Maharashtra, the area under guar is quite low but increasing year after year due to drought hardy nature and better performance under moisture stress situation compared to traditional legume crops. Therefore, it is of paramount importance to identify and develop an agronomical practice that influences the performance of guar and appropriate crop management to increase production potential and ensuring stable yields.

\section{Materials and methods}

An experiment was conducted on clay loam soil at Agronomy farm, Dr. Panjabrao Deshmukh Krishi Vidyapeeth, Akola during the summer season of 2015. To investigate the effect of irrigation levels and spacings on different phenophase and correlation coefficient of summer guar gum. Twelve treatment combinations consisted of four levels of irrigation levels viz., 0.6 IW/CPE, 0.8 IW/CPE, 1.0 IW/CPE and 1.2 IW/CPE as a main plot treatments and three levels of spacings viz., $30 \times 15 \mathrm{~cm}, 45 \times 10 \mathrm{~cm}$ and $60 \times 7.5 \mathrm{~cm}$ as sub plot treatments were evaluated using split plot design replicated thrice. Observations were recorded on different phenophase and yield attributing traits on randomly selected five plants. The data were analyzed as per Gomez and Gomez (1984) ${ }^{[1]}$ with the help of computer.

\section{Results and Discussion}

Effect of irrigation levels and spacings on days required for completion of different phenophases

The data recorded on days required for completion of different phenophases are presented in Table 1.
GN Yadav

Research Scholar,

Dr. Panjabrao Deshmukh Krshi

Vidyapeeth, Akola,

Maharashtra, India 
Table 1: Days required for completion of different phenophases as influenced by different irrigation levels and spacings

\begin{tabular}{|c|c|c|c|c|}
\hline Treatments & \multicolumn{4}{|c|}{ Days required for different phenophases } \\
\hline & $\mathbf{5 0} \%$ flowering & Pod initiation & Pod filling & Harvesting \\
\hline A) Main plot (Irrigation) & & & & \\
\hline I 1 (0.6IW/CPE) & 40.89 & 50.00 & 77.00 & 99.33 \\
\hline I 2 (0.8IW/CPE) & 41.22 & 51.78 & 78.33 & 99.89 \\
\hline I 3 (1.0IW/CPE) & 41.56 & 52.56 & 78.89 & 101.33 \\
\hline I 4 (1.2IW/CPE) & 42.11 & 53.67 & 79.00 & 101.56 \\
\hline SE(m)+ & 0.17 & 0.69 & 0.23 & 0.41 \\
\hline CD at 5 \% & 0.58 & 2.40 & 0.79 & 1.40 \\
\hline B) Sub-plot (Spacing) & & & & \\
\hline S 1 (30cm x 15cm) & 40.92 & 51.33 & 78.25 & 100.67 \\
\hline S 2 (45cm x 10cm) & 41.83 & 52.58 & 78.67 & 100.17 \\
\hline S 3 (60cm x 7.5cm) & 41.58 & 52.08 & 78.00 & 100.75 \\
\hline SE(m)+ & 0.26 & 0.48 & 0.32 & 0.24 \\
\hline CD at 5 \% & NS & NS & NS & NS \\
\hline C) Interaction (A x B) & 0.52 & 0.95 & 0.64 & 0.48 \\
\hline SE(m)+ & NS & NS & NS & NS \\
\hline CD at 5 \% & 41.44 & 52.00 & 78.31 & 100.53 \\
\hline GM & \multicolumn{4}{c}{}
\end{tabular}

\section{Days required for different phenophases}

Days required for completion of different phenophases were significantly influenced by irrigation level at $0.6 \mathrm{IW} / \mathrm{CPE}$ recorded significantly less days required for completion of different phenophases at growth stages i.e. 50\% flowering, pod initiation, pod filling stage and harvesting as compared to other irrigation levels. at 0 . IW/CPE was recorded significantly less days required for completion of. Significantly higher days required for completion of different phenophases was registered under irrigation schedule at 1.2 IW/CPE was higher days required for completion of different phenophases might be due to higher photo thermal units accumulated in higher moisture availability and moisture stress condition the forced maturity leads to early maturity due to higher temperature. Similar result was found (Esparza et al., 2007) ${ }^{[5]}$.

Completion of different phenophases was non significantly influenced by spacings at all the growth stages. Crop required less days for completion of pod initiation stage under spacing of $45 \times 10 \mathrm{~cm}$.

\section{Effect of Irrigation Levels and Spacings On Growing Degree Days $\left(\right.$ Day $\left.^{\circ} \mathrm{C}\right)$ By Crop}

The data recorded on growing degree days (day ${ }^{0} \mathrm{C}$ ) as influenced by various treatments are presented in Table 2 .

Table 2: Growing Degree Days $\left(\right.$ day $\left.{ }^{\circ} \mathrm{C}\right)$ as influenced by different irrigation levels and spacings

\begin{tabular}{|c|c|c|c|c|}
\hline Treatments & \multicolumn{4}{|c|}{ GDD (Growing Degree Days) } \\
\hline A) Main plot (Irrigation) & 50 \% flowering & Pod initiation & Pod filling & Harvesting \\
\hline I 1 (0.6IW/CPE) & 558.56 & 724.46 & 1258.88 & 1795.41 \\
\hline I 2 (0.8IW/CPE) & 566.78 & 760.20 & 1289.75 & 1810.31 \\
\hline I 3 (1.0IW/CPE) & 568.37 & 770.47 & 1302.57 & 1843.05 \\
\hline I 4 (1.2IW/CPE) & 577.31 & 797.63 & 1305.18 & 1843.71 \\
\hline SE(m)+ & 2.96 & 12.51 & 5.37 & 8.65 \\
\hline CD at 5 \% & 10.23 & 43.29 & 18.58 & 29.94 \\
\hline B) Sub-plot (Spacing) & & & & \\
\hline S 1 (30cm x 15cm) & 559.28 & 747.78 & 1287.99 & 1822.39 \\
\hline S 2 (45cm x 10cm) & 572.69 & 775.85 & 1297.27 & 1817.30 \\
\hline S 3 (60cm x 7.5cm) & 571.29 & 765.94 & 1282.03 & 1829.67 \\
\hline SE(m)+ & 3.91 & 10.37 & 7.40 & 6.33 \\
\hline CD at 5 \% & NS & NS & NS & NS \\
\hline C) Interaction (A x B) & & & & \\
\hline SE(m)+ & 7.81 & 20.74 & 14.80 & 12.65 \\
\hline CD at 5 \% & NS & NS & NS & NS \\
\hline GM & 567.76 & 763.19 & 1289.10 & 1823.12 \\
\hline
\end{tabular}

\section{Growing degree days $\left(\operatorname{day}^{0} \mathrm{C}\right)$}

Growing degree days (day ${ }^{\mathrm{O}} \mathrm{C}$ ) was significantly influenced by irrigation levels, irrigation level at 1.2 IW/CPE recorded significantly higher growing degree days $\left(\right.$ day $\left.{ }^{0} \mathrm{C}\right)$ at different phenophases i.e. 50\% flowering, pod initiation, pod filling and harvesting than other irrigation levels. It was followed by irrigation level at 1.0 IW/CPE. Significantly lower growing degree days (day ${ }^{\circ} \mathrm{C}$ ) was registered with crop irrigated on $0.6 \mathrm{IW} / \mathrm{CPE}$. The accumulation of higher growing degree days (day ${ }^{\mathrm{O}} \mathrm{C}$ ) might be due to higher photo thermal units accumulated in later growth stage. Higher growing degree days indicate less efficiency of crop to utilize natural resources and conversion of it into productivity. Similar result was found (Esparza et al., 2007) ${ }^{[5]}$

Growing degree days (day ${ }^{\circ} \mathrm{C}$ ) was non significantly influenced by spacings at all the critical growth stages. Spacing of $45 \times 10 \mathrm{~cm}$ was responsible for higher growing degree days (day ${ }^{\circ} \mathrm{C}$ ) at different phenophases i.e. $50 \%$ flowering, pod initiation and pod filling than other spacings but spacing of $60 \times 7.5 \mathrm{~cm}$ was responsible for higher growing degree days $\left(\right.$ day ${ }^{\circ} \mathrm{C}$ ) at harvesting stage. It was non significant than other spacings indicating that the more energy 
required for growth and productivity of the crop sown with 30 $\mathrm{x} 15 \mathrm{~cm}$. However, significantly lower growing degree days (day ${ }^{\circ} \mathrm{C}$ ) was observed with crop grown with $30 \times 15 \mathrm{~cm}$ at $50 \%$ flowering stage and pod filling. The GDD required less at harvesting stage with the spacing of $45 \times 10 \mathrm{~cm}$.

\section{Interaction effect}

Interaction effects of irrigation levels and spacings with respect to correlation coefficient and growing degree days found to be non significant.

\section{Correlation coefficients}

The correlation coefficients between yield and components trains are presented in Table 3.
Number of pods plant ${ }^{-1}$, number of seeds plant ${ }^{-1}$ showed highly significant correlations ( 0.747 and 0.719 , respectively) with seed yield plant ${ }^{-1}$. The correlation between number of branches and seed yield plant ${ }^{-1}$ was positive and significant (0.690). All other correlation with seed yield plant ${ }^{-1}$ were also positive and but not strongly correlated with yield components. These results supported by Kumar et al., (2002) [2]. He reported that among various characters influencing ultimate seed yield plant ${ }^{-1}$, number of pods plant ${ }^{-1}$, number ${\text { grains } \text { pod }^{-1} \text {, } 1000 \text { grain weight and grains plant }}^{-1}$, all had positive and significant association with final yield of mungbean.

Table 3: Correlation matrix between yield and yield components of guar gum

\begin{tabular}{|c|c|c|c|c|c|c|c|c|c|c|c|}
\hline $\begin{array}{c}\text { Simple } \\
\text { correlation }\end{array}$ & $\begin{array}{c}\text { Plant } \\
\text { height }\end{array}$ & $\begin{array}{l}\text { No. of } \\
\text { leaves }\end{array}$ & $\begin{array}{l}\begin{array}{l}\text { Leaf } \\
\text { area }\end{array} \\
\end{array}$ & $\begin{array}{c}\text { No. of } \\
\text { branches }\end{array}$ & $\begin{array}{c}\text { Dry } \\
\text { matter }\end{array}$ & $\begin{array}{c}\text { No. cluster } \\
\text { plant }^{-1}\end{array}$ & $\begin{array}{c}\text { pod } \\
\text { length }\end{array}$ & $\begin{array}{c}\text { No. of } \\
\text { pods }\end{array}$ & $\begin{array}{c}\text { No. of seed } \\
\text { pod }^{-1}\end{array}$ & $\begin{array}{c}\text { Seed yield } \\
\text { plant }^{-1}\end{array}$ & $\begin{array}{c}\text { Test } \\
\text { weight }\end{array}$ \\
\hline Plant height $(\mathrm{cm})$ & 1.000 & & & & & & & & & & \\
\hline No. of leaves & $0.918^{* *}$ & 1.000 & & & & & & & & & \\
\hline leaf area & $0.840^{* *}$ & $0.882^{* *}$ & 1.000 & & & & & & & & \\
\hline No. of branches & $0.705^{*}$ & $0.751^{*}$ & $0.832^{* *}$ & 1.000 & & & & & & & \\
\hline dry matter plant $^{-1}$ & $0.755^{*}$ & $0.823^{* *}$ & $0.904^{* * *}$ & $0.831^{* *}$ & 1.000 & & & & & & \\
\hline No cluster pod ${ }^{-1}$ & $0.767^{*}$ & $0.684^{*}$ & \begin{tabular}{|l|}
0.498 \\
\end{tabular} & 0.657 & 0.451 & 1.000 & & & & & \\
\hline pod length & $0.817^{*}$ & $0.668^{*}$ & 0.575 & $0.684^{*}$ & 0.499 & 0.261 & 1.000 & & & & \\
\hline No of pods & $0.884^{* *}$ & $0.835^{* *}$ & $0.754^{*}$ & 0.663 & $0.721^{* *}$ & 0.584 & 0.602 & 1.000 & & & \\
\hline No of seed pod ${ }^{-1}$ & $0.713^{*}$ & 0.591 & 0.604 & $0.785^{*}$ & 0.649 & 0.647 & $0.707^{*}$ & $0.749^{*}$ & 1.000 & & \\
\hline Seed yield plant ${ }^{-1}$ & 0.580 & 0.598 & 0.646 & $0.690^{*}$ & 0.650 & 0.412 & 0.433 & $0.747^{*}$ & $0.719^{*}$ & 1.000 & \\
\hline Test weight & $0.683^{*}$ & $0.738^{*}$ & $0.757^{*}$ & $0.825^{* *}$ & 0.617 & 0.637 & 0.661 & 0.572 & 0.632 & 0.572 & 1.000 \\
\hline
\end{tabular}

\section{References}

1. Gomez KA, Gomez AA. Statistical Procedures for Agricultural research, Second Edition. A Wiley Interscience Publication, John Wiley and Sons, New York. 1984, 89-90.

2. Kumar J, Singh H, Singh T, Singh VP. Seed yield, water use and water use efficiency of summer mungbean (Vigna radiata L.) as influenced by methods of sowing, irrigation and irrigation schedules. Crop Research Hisar. 2002; 24(2)296-298.

3. Parihar SS, Gajri PR, Narang RS. Scheduling irrigation to wheat using pan evaporation. Indian J, Agril. Sci., 1974; 44(9):567-71.

4. Uddin S, Parvin S. Yield Performance of Mungbean (Vigna radiata L.) as Influenced by Irrigation. International J. Agronomy and Plant Production. 2013; 4(S):3659-3667.

5. Esparza A, Gowda P, Baumhardt R, Marek T, Howell T. Heat unit availability for cotton production in the Ogallala Aquifer region of the United States. J Cotton Sci. 2007; 11:110-117. 